\title{
Size, physiological quality, and green seed occurrence influenced by seeding rate in soybeans
}

\section{Tamanho, qualidade fisiológica e ocorrência de sementes verdes de soja influenciados pela densidade de semeadura}

\author{
André Sampaio Ferreira ${ }^{1 *}$; Claudemir Zucareli; Alvadi Antonio Balbinot Junior ${ }^{3}$; \\ Flávia Werner'; ${ }^{1}$ Antonio Eduardo Coelho ${ }^{4}$
}

\begin{abstract}
The seeding rate influences the intraspecific competition, which might affect the development and quality of seeds in soybean. However, the impact of seeding rate on the physical and physiological qualities of soybean seeds needs to be better elucidated. This study aimed to evaluate the effects of soybean plant density on the seed size as well as the effects of the interaction between the plant density and seed size on the seed mass, green seed occurence, and physiological seed quality. The experiments were carried out in the growing seasons of the years 2013/14 and 2014/15 in a Latossolo Vermelho distroférrico, under a randomized complete block design, using the NK 7059 RR cultivar with six replications. Four plant densities $\left(150,300,440\right.$, and 560 thousand viable seeds ha $\left.{ }^{-1}\right)$ were evaluated. After the classification of seeds into four sizes, using a set of sieves, a $4 \times 4$ factorial scheme was used for the statistical analysis of the four plant densities and four seed sizes. The seed samples were evaluated for the seed mass, green seed percentage, germination, and vigor. Under thermal and water stress during seed development, an increase in the seeding rate led to a reduction in the green seed occurrence and an increase in the seed size and mass. However, in the absence of thermal and water stress, the seed size and mass were not altered by the seeding rate and, there was no occurrence of green seeds.
\end{abstract}

Key words: Plant density. Chlorophyll retention. Green seeds. Seed vigor.

\section{Resumo}

A densidade de semeadura, por influenciar na competição intraespecífica, pode afetar o desenvolvimento e a qualidade das sementes de soja produzidas. Entretanto, o impacto da densidade de semeadura sobre a qualidade física e fisiológica das sementes de soja precisa ser melhor elucidado. Objetivou-se avaliar os efeitos da densidade de semeadura sobre o tamanho das sementes produzidas e a interação entre a densidade de semeadura e o tamanho das sementes sobre a massa, a ocorrência de sementes verdes e a qualidade fisiológica das mesmas. O experimento foi conduzido nas safras 2013/14 e 2014/15, em um Latossolo Vermelho distroférrico, sob o delineamento de blocos casualizados, utilizando-se a cultivar NK7059 RR, com seis repetições. Os tratamentos consistiram de quatro densidades de semeadura (150, 300, 440 e 560 mil sementes viáveis ha-1 ${ }^{-1}$. Após a classificação em peneiras das sementes produzidas, adotou-se o esquema fatorial 4 x 4, com 4 densidades e 4 tamanhos de sementes. Avaliaram-se a massa de mil sementes, porcentagem de sementes verdes, germinação e vigor. $\mathrm{O}$ aumento na densidade de

\footnotetext{
${ }^{1}$ Discentes, Curso de Doutorado do Programa de Pós-Graduação em Agronomia, UEL, Londrina, PR, Brasil. E-mail: andresampaioferreira@gmail.com; fla_werner@hotmail.com

2 Prof. Dr., Departamento de Agronomia, Centro de Ciências Agrárias, UEL, Londrina, PR, Brasil. E-mail: claudemircca@uel.br

3 Pesquisador, Embrapa Soja, Londrina, PR, Brasil.-Email: alvadi.balbinot@embrapa.br

${ }^{4}$ Discente, Curso de Mestrado do Programa de Pós-Graduação em Produção Vegetal, UDESC, Lages, SC, Brasil. E-mail: coelhoagro7@gmail.com

* Author for correspondence
} 
semeadura reduz a porcentagem de sementes verdes e incrementa o tamanho e a massa de sementes, em condições de estresse térmico e hídrico durante a fase de formação das mesmas. O tamanho e massa de sementes não são alterados pela densidade de semeadura na ausência de estresse térmico e hídrico e, nesses casos, não há ocorrência de sementes verdes de soja.

Palavras-chave: Densidade de plantas. Retenção de clorofila. População de plantas. Qualidade fisiológica.

\section{Introduction}

The productivity of soybean seeds has low response to plant density variations (BALBINOT JUNIOR et al., 2015; BOARD; KAHLON, 2013; PROCÓPIO et al., 2014.). Soybean plants have high phenotypic plasticity, that is, high ability to adapt to the environmental and handling conditions by undergoing changes in their phenotypic traits, such as morphology architecture, and yield components (DE LUCA et al., 2014), which might vary according to the plant density with a compensating effect, while maintaining the productivity of soybean seeds (COX; CHERNEY, 2011).

The production of soybeans in Brazil, as in other countries, has been affected by the phenomenon of chlorophyll retention in the seeds that results in the production of green seeds (ZORATO et al., 2007). This phenomenon occurs due to the biotic and abiotic factors that can lead to the premature death of plants, and results in the forced maturation of the seeds, preventing the complete degradation of chlorophyll and causing rapid translocation of the reserves, thus lowering the rates of photosynthesis, and hence productivity (RANGEL et al., 2011). Among the environmental stresses, the occurrence of high summer temperatures, during the maturation period of soybean, is the main factor responsible for chlorophyll retention, causing severe losses to seed productivity and quality (FRANÇA-NETO et al., 2012). In conditions of the water stress associated with excessive heat, the crops with relatively high plant densities might have marked intraspecific competition (DE BRUIN; PEDERSEN, 2008), favoring high production of the green seeds with reduced size and low physiological quality.
The development of soybean seeds depends on the supply of photoassimilates, which is influenced by the position of pods in a plant (PADUA et al., 2009). Therefore, the changes in plant morphology and architecture caused by changes in plant density might change the distribution of the pods in a soybean plant, affecting the partitioning of photoassimilates, thus causing changes in the size and quality of the seeds produced.

In addition, some studies have shown that the soybeans seeds with relatively larger size present relatively higher quality, resulting in plants with relatively higher growth and productivity (PARDO et al., 2015, PEREIRA et al., 2013). However, some studies have reported divergent results, in which the influence of seed size on yield components (SOARES et al., 2013), seed oil and protein content, and productivity was observed (MOURTZINIS et al., 2015).

The hypothesis of this research is that an increase in the soybean-seeding rate accentuates the intraspecific competition, which might cause a reduction in the size, mass, and physiological quality of the seeds, and, in the event of water stress and excessive heat during seed formation, might cause an increase in the occurrence of green seeds. Thus, the objective of this work was to evaluate the effects of the soybean-seeding rate on the size of the seeds produced and the effect of the interaction between seeding rate and seed size on the occurrence of green seeds, physiological quality, and mass of the seeds, in two crops with contrasting climatic conditions. 


\section{Material and Methods}

This study was carried out in three stages. The first step consisted of conducting a field experiment in the same area $\left(23^{\circ} 19^{\prime} 21^{\prime \prime} \mathrm{S}, 51^{\circ} 20^{\prime} 46^{\prime \prime} \mathrm{W}\right.$; altitude $620 \mathrm{~m}$ ) in 2 consecutive years, 2013/14 and 2014/15. The climate of this region was classified as humid subtropical (Cfa), according to the Köppen classification. The data of rainfall and the minimum, medium, and maximum air temperatures during the period between sowing and harvesting were collected at the Embrapa Soja agrometeorological station, at a distance of approximately $500 \mathrm{~m}$ from the experimental site. The data are presented in the periods of 10 days (Figure 1).

Figure 1. Rainfall (total accumulated during the ten-day period) and minimum, average, and maximum temperatures during the experimental period. Londrina, 2013/14 (a) and 2014/15 crops (b).

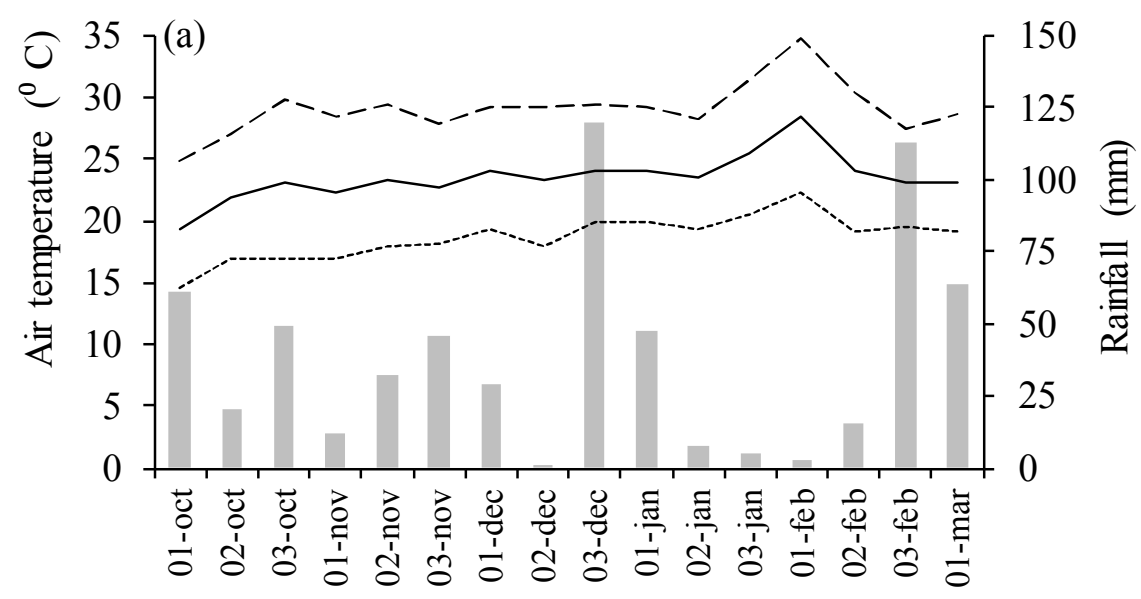

ten-day period - months

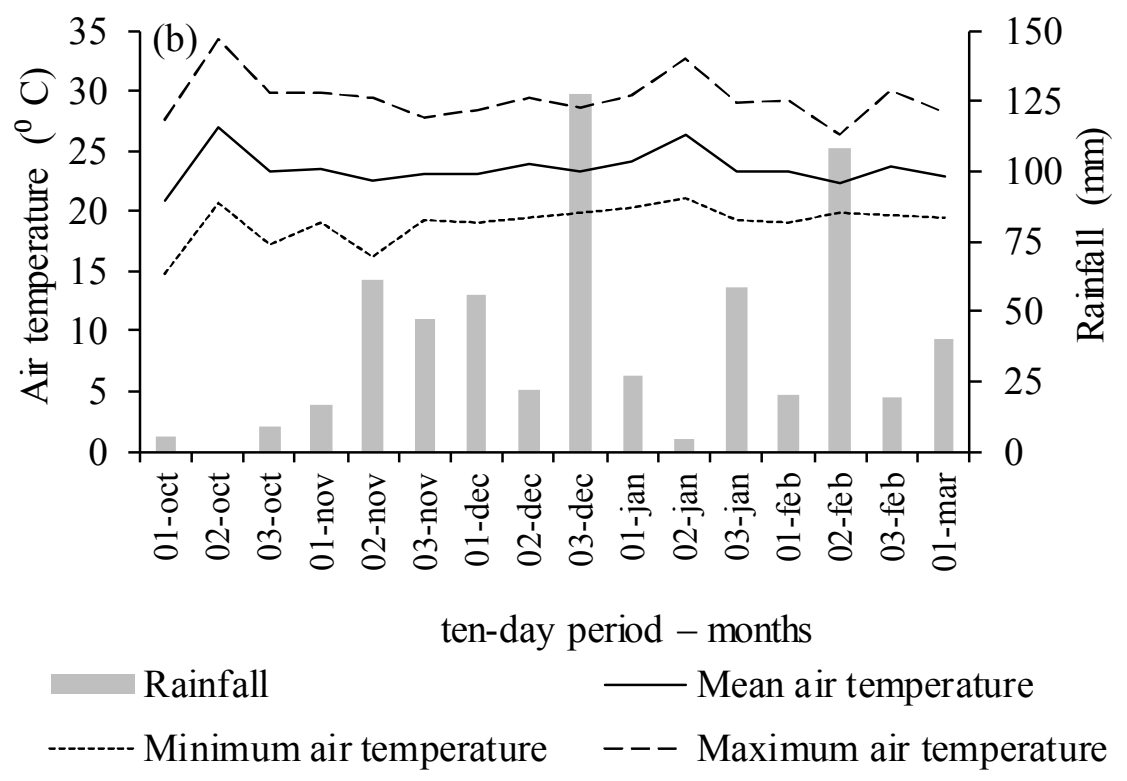

The soil of the experimental area was classified as Latossolo Vermelho distroférrico. It comprised of the following chemical components in the $0-20-\mathrm{cm}$ layer before the implementation of the experiments: organic carbon $\left(21.4 \mathrm{~g} \mathrm{dm}^{-3}\right), \mathrm{CaCl}_{2}(\mathrm{pH} 4.9), \mathrm{P}$ $\left(8.6 \mathrm{mg} \mathrm{dm}^{-3}\right), \mathrm{K}\left(0.55 \mathrm{cmol} \mathrm{c} \mathrm{dm}^{-3}\right), \mathrm{Ca}(3.7 \mathrm{cmol}$ $\left.\mathrm{c} \mathrm{dm}{ }^{-3}\right), \mathrm{Mg}\left(1.4 \mathrm{cmol} \mathrm{c} \mathrm{dm}^{-3}\right)$, and $48 \%$ cation exchange capacity saturation per base. In both 
experiments, the no-tillage system on wheat straw was used for the 2013/14 crop and that on black oats was used for the 2014/15 crop.

The experimental design of the randomized complete blocks with six replications was used. Four sowing densities $(150,300,440$, and 560 thousand viable seeds $\mathrm{ha}^{-1}$ ) of the cultivar NK7059 RR was evaluated, which shows an indeterminate type of growth with a relative maturity grouping of 5.9. The experimental plots were 10.0-m long and 5.0-m wide, and the intra-row spacing was $0,5 \mathrm{~m}$.

Seeding was carried out on 10/23/2013 and 10/28/2014. The seeds were treated with ThiramVitavax $200 \mathrm{SC}{ }^{\circledR}(3 \mathrm{ml}$ carboxin + thiram solution $\mathrm{kg}^{-1}$ of seeds) Co-Mo Platinum ${ }^{\circledR}\left(2 \mathrm{~mL} \mathrm{~kg}^{-1}\right.$ of seeds), and liquid inoculant Gelfix $5{ }^{\circledR}$ containing 5 $\times 10^{9}$ colony-forming units of $\mathrm{N}$ fixing bacteria $\mathrm{mL}^{-1}$ ( $2 \mathrm{~mL} \mathrm{~kg}^{-1}$ of seeds). In the $2014 / 15$ harvest, due to the drought in October, the area was irrigated with a 30-mm blade, two days after sowing to ensure seedling emergence.

The basic fertilization consisted of the application of $600 \mathrm{~kg} \mathrm{ha}^{-1}$ of simple superphosphate and $250 \mathrm{~kg} \mathrm{ha}^{-1}$ of potassium chloride for both growing seasons. The control of pests, diseases, and weeds was carried out according to the technical indications for the crop. The harvest was carried out at the R8 stage without the desiccation of soybean plants with an automotive combined harvester in 4 lines of the central part of the plot and the harvested area was $12 \mathrm{~m}^{2}$ (8-m long and 1.5-m wide).

\section{Classification of seeds}

In this first stage, the classification of the seeds produced in different sieve sizes was performed. A 2-kg subsample of the seeds harvested in each plot was classified into four levels using the uniformity test adapted from the Rules for Seed Analysis (BRASIL, 2009). The oblong sieves of the following sizes were used: $11 \times 3 / 4$ " $(4.36 \times$ $19.05 \mathrm{~mm}), 12 \times 3 / 4$ " $(4.76 \times 19.05 \mathrm{~mm}), 13 \times 3 / 4$ "
$(5.16 \times 19.05 \mathrm{~mm})$, and $14 \times 3 / 4 "(5.56 \times 19.05$ $\mathrm{mm})$ for the $2013 / 14 \mathrm{crop}$, and $13 \times 3 / 4$ " $(5.16 \times$ $19.05 \mathrm{~mm}), 14 \times 3 / 4$ " $(5.56 \times 19.05 \mathrm{~mm}), 15 \times 3 / 4$ " $(5.95 \times 19.05 \mathrm{~mm})$, and $16 \times 3 / 4 "(6.35 \times 19.05$ $\mathrm{mm}$ ) for the $2014 / 15$ crop. Owing to the difference in the sizes of the seeds produced in each crop, the different sieves were used for the two harvests. The results were expressed as the percentage of the seed mass retained in each sieve and the percentage not retained in any of the sieves (discard).

Evaluation of the mass of 1000 seeds and the occurrence of green seeds

At this stage, a completely randomized $4 \times 4$ factorial experimental design was used with six replications. Four sowing densities $(150,300,440$, and 560 thousand viable seeds $\left.\mathrm{ha}^{-1}\right)$ and four seed sizes (retained on the sieves: $11 \times 3 / 4$ ", $12 \times 3 / 4$ ", $13 \times 3 / 4$ ", and $14 \times 3 / 4$ " of the $2013 / 14$ crop and 13 $\times 3 / 4$ ", $14 \times 3 / 4$ ", $15 \times 3 / 4$ ", and $16 \times 3 / 4$ " of the $2014 / 15$ crop) were used. At this stage, the mass of one thousand seeds and the percentage of green seeds in each sieve were determined, separately. The mass of a thousand seeds was evaluated according to the methodology defined in the Rules for Seed Analysis (BRASIL, 2009). The identification of the green seeds was carried out by using the same evaluators, in order to standardize the classification. The seeds that exhibited any level of greenish coloration in their integument were considered green seeds.

\section{Evaluation of the physiological quality of seeds}

Laboratory analyses of the physiological quality of seeds were carried out. However, the results of the germination test for the seeds of the 2013/14 crop were found to be less than the standards for seed marketing (80\%). This was because of the poor seed formation due to the high temperature and low rainfall during the period of seed filling extending from the second 10-day period of January to the second 10-day period of February (Figure 
1A). Therefore, the other tests of the physiological quality of the seeds produced in this harvest were not followed up.

The physiological quality of the seeds was evaluated through the following tests:

a) Germination: Conducted with eight replicates of 50 seeds in germitest paper moistened in the proportion 2.5:1 (distilled water in $\mathrm{mL}$ : weight of dry paper in grams) and kept in a germination chamber under controlled temperature of $25 \pm$ $1 \mathrm{C}$ for $8 \mathrm{~d}$. The results were expressed as the percentage of normal germinated seedlings, according to the Rules for Seed Analysis (BRASIL, 2009).

b) Field seedling emergence: This test was performed in four replicates by sowing 100 seeds and counting at 21 days after sowing (DAS), when the cotyledons were completely open and the primary leaves differentiated (NAKAGAWA, 1999).

c) Seedling length: This test was performed according to the methodology proposed by Nakagawa (1999). The test was performed in a germitest paper roll with 10 seeds and addition of distilled water in the proportion of 2.5 times the mass of the substrate paper, with four replicates. The seeds were positioned with the micropyle facing the top of the paper. After five days, the lengths of the seedlings were measured, and the results were expressed in centimeters.

d) Dry mass of seedlings: Normal seedlings obtained from the seedling length test, excluding cotyledons, were evaluated. The replicates of each plot were packed in paper bags and taken to the stove with forced air circulation maintained at $80{ }^{\circ} \mathrm{C}$ for a period of $24 \mathrm{~h}$ (NAKAGAWA, 1999). Subsequently, the samples were weighed on a precision scale, and the results were expressed in milligrams.

\section{Statistical analysis}

The data were submitted to the analysis of variance for the comparison of averages by Tukey's test $(p \leq 0.05)$ for the sieve factor. For the seeding rate factor, the unfolding of the sum of squares was applied to the orthogonal polynomials until the second degree $(p \leq 0.05)$.

\section{Results and Discussion}

The tested sowing densities provided the following plant densities at harvest: $135,235,315$, and 440 thousand plants $\mathrm{ha}^{-1}$ in the 2013/14 crop and $105,210,345$, and 430 thousand plants $\mathrm{ha}^{-1}$ in the 2014/15 crop. These results showed that the plant densities at harvest were well below the desired densities at sowing. These findings were in agreement with the results of Cox and Cherney (2011) and Suhre et al. (2014). These authors reported that many biotic and abiotic factors, such as machinery malfunction, seed diseases, soil compaction and hail rain, interfere in the establishment of a stand.

\section{Classification of seeds}

In the 2013/14 harvest, we observed a significant effect of the seeding rate on their retention in sieves, showing an increase in the seed size with an increase in the seeding rate (Figure 2). The lower density (150,000 viable seeds $\mathrm{ha}^{-1}$ ) showed the relatively higher amounts of the seeds classified as discard and sieve $11 \times 3 / 4$ ", and smaller amounts of the seeds classified as sieves $13 \times 3 / 4$ " and $14 \times 3 / 4$ ". In contrast, the greater density $(560,000$ viable seeds $\mathrm{ha}^{-1}$ ) showed a higher number of seeds classified as sieves $13 \times 3 / 4$ " and $14 \times 3 / 4$ " and relatively less seeds classified as discard and sieve $11 \times 3 / 4$ ". The percentage of the seeds classified in sieves 12 $\times 3 / 4$ " (intermediate size) showed low variation in response to the density. Furthermore, Kuss et al. (2008) found an increase in the size of soybean due to an increase in the density from 250 to 400,000 plants $\mathrm{ha}^{-1}$, especially in drought situations. 
Figure 2. Percentage of seeds classified on the four sieve sizes $11 \times 3 / 4$ ", $12 \times 3 / 4 ", 13 \times 3 / 4$ ", and $14 \times 3 / 4$ " according to the four sowing densities $\left(150,300,440\right.$ and 560 thousand viable seeds $\left.\mathrm{ha}^{-1}\right)$. Londrina, 2013/14 crop.

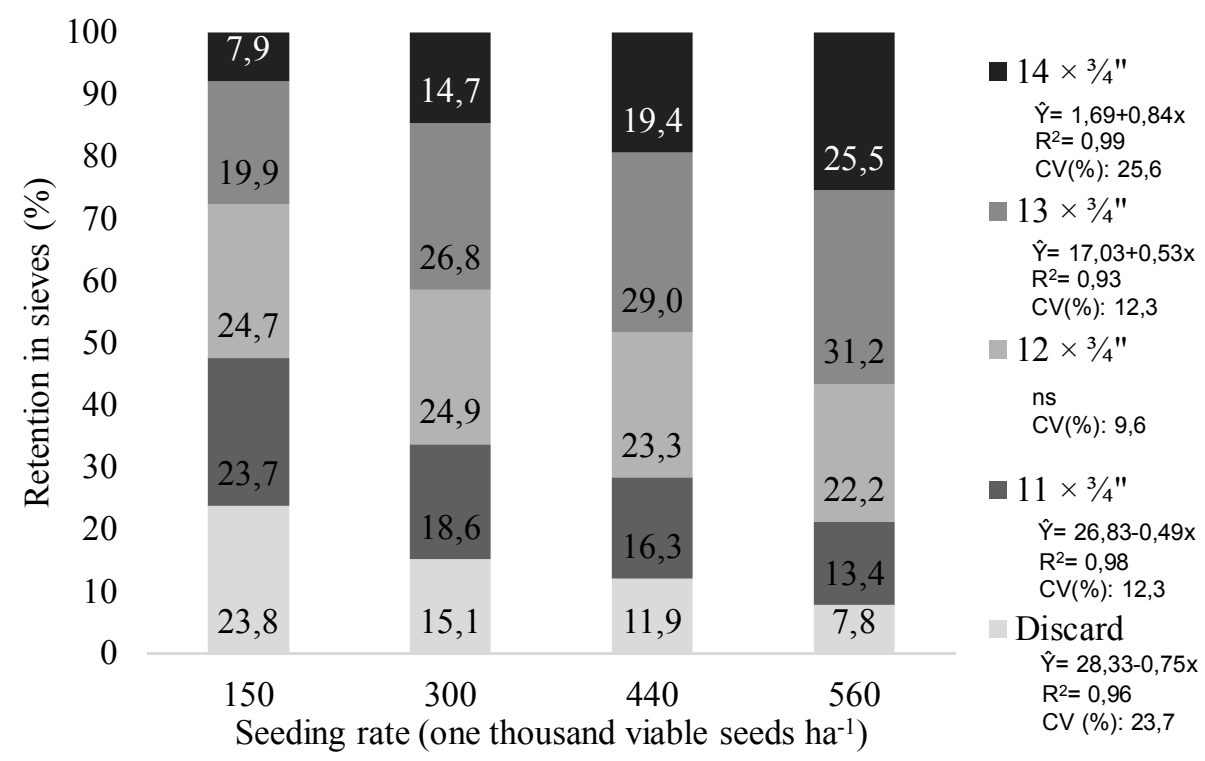

The effect of the seeding density on seed size was not observed in the 2014/15 crop (Figure $3)$. Even with wide variation in the seeding density, the classification of seeds on sieves was similar between treatments, and on an average, $60 \%$ of the seeds were classified as sieve $15 \times 3 / 4$ " and $20 \%$ as sieve $16 \times 3 / 4 "$.

In the 2013/14 crop, low rainfall associated with high temperatures was observed during the seed filling phase - a period including the second ten-day period from January to the second ten-day period of February (Figure 1). Therefore, in the regions with higher plant density, there was possibly a deepening of soybean roots during the vegetative phase. This was due to the greater intraspecific competition, as discussed by Carlesso (1995), providing a greater volume of the soil explored in the water-stress phase. Additionally, the leaf area index (LAI) and transpiration in the grain filling stage were poorly affected by the plant density when the climatic conditions allowed adequate soybean growth in the vegetative phase according to the phenotypic plasticity of plants (PROCÓPIO et al., 2014), which was observed in the 2013/14 harvest. It is probable, therefore, that with increasing plant density, a greater efficiency was observed in the exploration of the soil water in depth. On the other hand, the water consumption by evapotranspiration was little affected by the plant density, improving the water supply in the plants cultivated at higher densities.

At higher densities, there is a lower percentage of the seeds derived from the branches (BALBINOT JUNIOR et al., 2015; PROCÓPIO et al., 2013), which have a low demand for photoassimilates as compared to that of the seeds produced on the stems. Thus, under stress in the filling stage, there is greater availability of photoassimilates to the seeds produced on the main stem in detriment to those produced on the branches. Frederick et al. (2001) concluded that the contribution of branches to seed productivity is highly influenced by water availability, whereas the seed production of the main stem is quite stable; thus, the contribution of the main stem for seed productivity is relatively higher in the years of drought. These factors underlie the formation of larger seeds as the density increased from 150 to 560 thousands $\mathrm{h}^{-1}$ viable seeds under the conditions of thermal and water stress during seed formation. 
Figure 3. Percentage of seeds classified on the four sieve sizes $13 \times 3 / 4$ ", $14 \times 3 / 4 ", 15 \times 3 / 4$ ", and $16 \times 3 / 4$ " according to the four sowing densities $\left(150,300,440\right.$, and 560 thousand viable seeds ha $\left.{ }^{-1}\right)$. Londrina, 2014/15 crop.

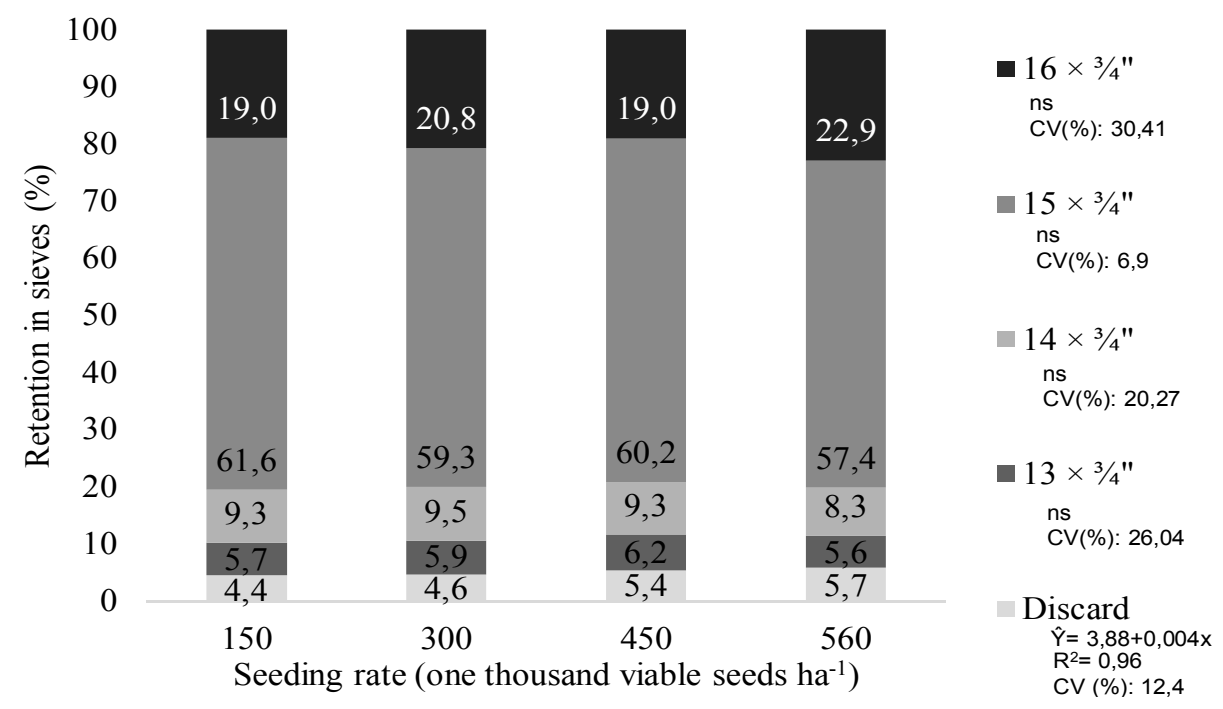

The absence of the seeding rate effect on seed size produced in the 2014/15 crop was associated with the better distribution of rainfall and warmer temperatures during the whole season (Figure 1). Therefore, the ambiental resources was sufficient to supply the plants in demand, allowing adequate seed development at all tested densities. This showed that the effect of seeding rate on the size of soybean seeds was strongly influenced by the edaphoclimatic conditions during the crop development cycle. However, it is relevant to conduct new studies for evaluating the production of soybean seeds in response to the seeding rate and climatic conditions at different stages of the plant development.
Evaluation of the mass of one thousand seeds and the percentage of green seeds

No interaction was observed between the seeding rate and seed size for the characteristic mass of one thousand seeds. In the 2013/14 crop, we observed a linear increase in the mass of one thousand seeds as a function of the increase in density (Figure 4). This result indicates that in this harvest, the seeds formed by plants growing at a higher density showed bettersuited conditions for their formation. In the 2014/15 crop, no effect of the seeding density was observed on the mass of one thousand seeds (Figure 4). The seed mass in the 2014/15 crop was significantly higher than the previous harvest, evidencing that the seeds in this harvest developed under more adequate conditions than in 2013/14. The more favorable climatic conditions in the second harvest attenuated the intraspecific competition, and an increase in plant density did not limit the filling of the seeds. 
Figure 4. Mass of one thousand seeds (g) at different seeding rates $(150,300,440$, and 560 thousand viable seeds ha $^{-1}$ ). Londrina, 2013/14 and 2014/15 crops.

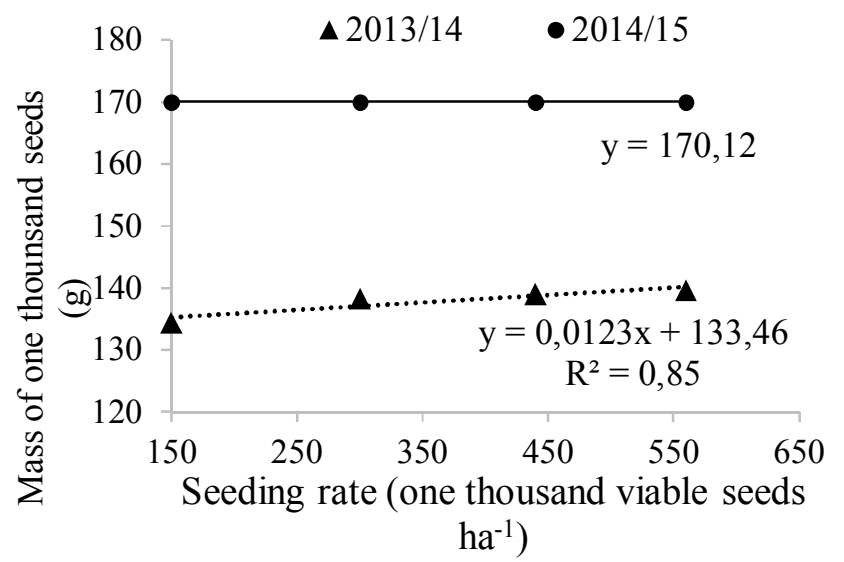

In the 2013/14 crop, the occurrence of green seeds was affected by the seeding rate (Figure 5) and seed size (Table 1). We observed a linear reduction in the percentage of green seeds with an increase in the seeding rate. In contrast to what was hypothesized, an increase in the intraspecific competition caused by a higher plant density (SOUZA et al., 2010), especially when associated with water and thermal stress, did not provoke forced maturation of the seeds, causing the retention of chlorophyll in the cotyledons. This result reinforces the aforementioned theory that supported the production of larger seeds at high plant densities, since the best water supply at high densities prevented the forced degradation of chlorophyll, and thus, the maintenance of the greenish color in the seeds. Moreover, the highest proportion of pods was observed in the main stem in the high-density plots, considering that the leaves located in the main stem presented greater photosynthetic efficiency than the branches (KOKUBUN; ASAHI, 1984).

These results, in contrast to the hypothesis raised by this research, represent a highly relevant information for the soybean seed-production chain in Brazil. It is well-known that in Brazil, a large part of the soybean cultivation for seed or grain production occurs in the tropical climate, wherein the occurrence of water deficit associated with excessive heat in the reproductive phase is relatively common. In this situation, special care should be taken to obtain the appropriate stand, as the low sowing densities might result in a higher percentage of green seeds.

Figure 5. Percentage of green seeds concerning sowing densities $\left(150,300,440\right.$, and 560 thousand viable seeds ha $\left.{ }^{-1}\right)$ (average of four seeds sizes). Londrina, 2013/14 crop. CV: 31.5\%.

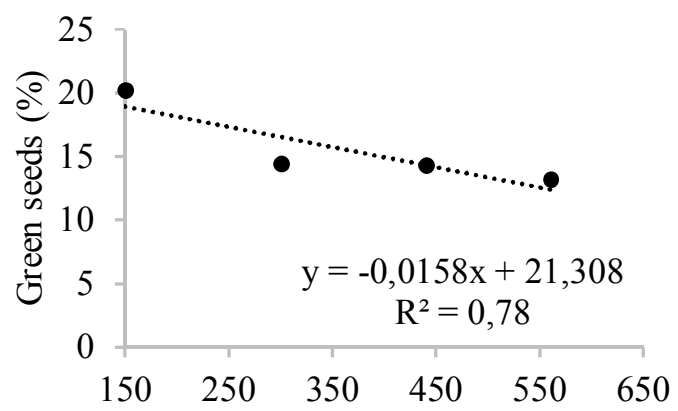

Seeding rate (one thousand viable seeds $\left.\mathrm{ha}^{-1}\right)$ 
Table 1. Percentage of green seeds as the function of seed sizes (average of four sowing densities). Londrina, 2013/14 crop.CV: $31.5 \%$.

\begin{tabular}{ccccc}
\hline & \multicolumn{4}{c}{ Sieves } \\
\hline \multirow{2}{*}{ Green seeds $(\%)$} & $11 \times 3 / 4 "$ & $12 \times 3 / 4 ”$ & $13 \times 3 / 4 ”$ & $14 \times 3 / 4 "$ \\
\cline { 2 - 5 } & $8.2 \mathrm{c}^{*}$ & $10.9 \mathrm{c}$ & $18.3 \mathrm{~b}$ & $24.9 \mathrm{a}$ \\
\hline
\end{tabular}

${ }^{*}$ Averages followed by the same letters in the lines do not differ by Tukey's test $(p \leq 0.05)$.

Among the four sowing densities, a higher percentage of green seeds was found among the larger seeds (Table 1). Probably, the larger seeds, during their filling stage, had a higher amount of chlorophyll and photoassimilates due to a greater demand and, with the strong water and thermal stress, a forced maturation of the seed was induced, preventing the degradation of chlorophyll presented in high quantity (FRANÇA-NETO et al., 2012). In the 2014/15 crop, no green seeds were observed because of the absence of high water and thermal stress (Figure 1), which are preponderant conditions for the retention of the chlorophyll in cotyledons (RANGEL et al., 2011) as in the previous crop.

\section{Evaluation of physiological quality of seeds}

Itwas verified that therewasnointeractionbetween the experimental factors for any of the variables of physiological seed quality. The germination and total seedling length were not affected alone by any of the experimental factors. Although the differences were not significant, the averages of the obtained germinations are presented in Table 2.

The field emergence and dry mass of seedlings were affected alone by the seed size (Table 3 ). The average field emergence of the seeds retained in the $13 \times 3 / 4$ " sieve was approximately $4 \%$ lower than that of the seeds retained in the $15 \times 3 / 4$ " and $16 \times 3 / 4$ " sieves. The seedling dry mass was relatively lower in the seeds retained in the $13 \times 3 / 4$ " sieve and larger in those retained in the $16 \times 3 / 4$ " sieve.

Table 2. Soybean seed germination (\%) produced under different sowing densities and classified by sieves sizes - the differences between treatments were not significant $(p=0.05)$. Londrina, 2014/15 crop. CV (\%): 9.3 .

\begin{tabular}{ccccc}
\hline & \multicolumn{4}{c}{ Sieves } \\
\cline { 2 - 4 } Density* & $13 \times 3 / 4 "$ & $14 \times 3 / 4 "$ & $15 \times 3 / 4 "$ & $16 \times 3 / 4 "$ \\
\cline { 2 - 4 } & \multicolumn{4}{c}{ Germination $(\%)$} \\
\hline 150 & 82.7 & 72.5 & 84.7 & 87.2 \\
300 & 87.7 & 80.2 & 87.0 & 85.7 \\
440 & 83.5 & 79.7 & 90.2 & 91.7 \\
\hline 560 & 81.0 & 82.6 & 82.0 & 79.7 \\
\hline
\end{tabular}

*(One thousand viable seeds ha $\left.{ }^{-1}\right)$.

Table 3. Field emergence and dry mass of seedlings in four seed sizes (average of four sowing densities). Londrina, 2014/15 crop.

\begin{tabular}{cccccc}
\hline & \multicolumn{5}{c}{ Sieves } \\
\cline { 2 - 6 } Field emergence (\%) & $13 \times 3 / 4 "$ & $14 \times 3 / 4 "$ & $15 \times 3 / 4 ”$ & $16 \times 3 / 4 ”$ & CV (\%) \\
\cline { 2 - 6 } & $89.63 \mathrm{~b}$ & $93,13 \mathrm{ab}$ & $94.00 \mathrm{a}$ & $93.50 \mathrm{a}$ & 4.37 \\
Seedling dry mass (mg) & $31.16 \mathrm{c}$ & $34.87 \mathrm{~b}$ & $35.82 \mathrm{~b}$ & $41.14 \mathrm{a}$ & 7.33 \\
\hline
\end{tabular}

* Averages followed by the same letter in the row do not differ statistically from each other by the Tukey's test ( $p \leq 0.05)$. 
The low influence of the experimental factors on the seed quality of the 2014/15 crop was due to the absence of stress during seed formation. In this harvest, a homogeneity was observed in the size of the seeds produced $(80 \%$ classified as $15 \times 3 / 4$ " and $16 \times 3 / 4$ "), indicating that the seed filling showed no limitation, regardless of the seeding rate. A relatively greater effect on the seed quality was expected for the 2013/14 crop; however, the environmental stress occurred during seed formation was so high that it reduced the germination to a level below the minimum standard required by the legislation.

It is noteworthy that even the seeds of the 2014/15 crop presented a percentage of the germination close to the minimum tolerated limit $(80 \%)$ for commercialization. According to França-Neto et al. (2010), the production of high quality soybean seeds requires the maturation and harvesting phases under mild temperatures, approximately $22{ }^{\circ} \mathrm{C}$, associated with dry climatic conditions. Such conditions can usually occur in the areas at an altitude of more than $700 \mathrm{~m}$, or latitude greater than $24^{\circ} \mathrm{S}$, which justifies the quality of the results obtained in this study that was conducted at an altitude of $620 \mathrm{~m}$ and a latitude of $23^{\circ} \mathrm{S}$.

In this context, our results suggest that seeding rate and seed size have little relevance on the variables associated with the physiological quality of the seeds in the absence of stresses during their formation. However, further studies are needed to elucidate the effects of seeding density on the physiological quality of the soybean seeds produced under water and thermal stresses at different stages of seed development.

\section{Conclusions}

An increase in the seeding rate reduces the percentage of green seeds and increases the seed size and mass under thermal and water stress conditions during the seed formation phase in soybean. However, in the absence of thermal and water stress, the seed size and mass are not altered by the seeding rate, and there is no occurrence of the green soybean seeds.

\section{References}

BALBINOT JUNIOR, A. A.; PROCÓPIO, S. O.; DEBIASI, H.; FRANCHINI, J. C.; PANISON, F. Semeadura cruzada em cultivares de soja com tipo de crescimento determinado. Semina: Ciências Agrárias, Londrina, v. 36, n. 3, p. 1215-1226, 2015.

BOARD, J. E.; KAHLON, C. S. Morphological responses to low plant population differ between soybean genotypes. Crop Science, Madison, v. 53, n. 3, p. 11091119, 2013.

BRASIL. Ministério da Agricultura, Pecuária e Abastecimento. Regras para análise de sementes. Ministério da Agricultura, Pecuária e Abastecimento. Secretaria de Defesa Agropecuária. Brasília: MAPA/ ACS, 2009. 395 p.

CARLESSO, R. Absorção de água pelas plantas: água disponível versus extraível e a produtividade das culturas. Ciência Rural, Santa Maria, v. 25, n. 1, p. 183-188, 1995.

COX, W. J.; CHERNEY, J. H. Growth and yield responses of soybean to row spacing and seeding rate. Agronomy Journal, Madison, v. 103, n. 1, p. 123-128, 2011.

DE BRUIN, J. L.; PEDERSEN, P. Effect of row spacing and seeding rate on soybean yield. Agronomy Journal, Madison, v. 100, n. 3, p. 704-710, 2008.

DE LUCA, M. J.; NOGUEIRA, M. A.; HUNGRIA, M. Feasibility of lowering soybean planting density without compromising nitrogen fixation yield. Agronomy Journal, Madison, v. 106, n. 6, p. 2118-2124, 2014.

FRANÇA-NETO, J. B.; KRZYZANOWSKI, F. C.; HENNING, A. A.; PADUA, G. P. Tecnologia da produção de semente de soja de alta qualidade. Informativo Abrates, Londrina, v. 20, n. 3, p. 37-38, 2010.

FRANÇA-NETO, J. B.; PÁDUA, G. P.; KRZYZANOWSKI, F. C.; CARVALHO, M. L.; HENNING, A. A.; LORINI, I. Semente esverdeada de soja: causas e efeitos sobre o desempenho fisiológico - série sementes. Londrina: Embrapa Soja, 2012. 16 p. (Embrapa Soja, Circular técnica, 91).

FREDERICK, J. R.; CAMP, C. R.; BAUER, P. J. Drought-stress effects on branch and mainstem seed yield and yield components of determinate soybean. Crop Science, Madison, v. 41, n. 3, p. 759-763, 2001. 
KOKUBUN, M.; ASAHI, Y. Source-sink relationships between the main stem and branches during reproductive growth in soybean. Japanese Journal of Crop Science, Tokyo, v. 53, n. 4, p. 455-462, 1984.

KUSS, R. C. P.; KONIG, O.; DUTRA L. M. C.; BELLÉ, R. A.; ROGGIA, S.; STURMER, G. R. Populações de plantas e estratégias de manejo de irrigação na cultura da soja. Ciência Rural, Santa Maria, v. 38, n. 4, p. 11331137, 2008.

MOURTZINIS, S.; GASKA, J. M.; PEDERSEN, P.; CONLEY, S. P. Effect of seed mass and emergence delay on soybean yield and quality. Agronomy Journal, Madison, v. 107, n. 1, p. 181-186, 2015.

NAKAGAWA, J. Testes de vigor baseados no desempenho de plântulas. In: KRZYZANOWSKI, F. C.; VIEIRA, R. D.; FRANÇA NETO, J. B. (Ed.). Vigor de sementes: conceitos e testes. Londrina: ABRATES, 1999. p. 1-21.

PADUA, G. P.; CARVALHO, M. L. M.; FRANÇANETO, J. B.; GUERREIRO, M. C.; GUIMARÃES, R. M. Response of soybean genotypes to the expression. of green seed under temperature and water stresses. Revista Brasileira de Sementes, Londrina, v. 31, n. 3, p. 140-149, 2009.

PARDO, F. F.; BINOTTI, F. F. S.; CARDOSO, E. D.; COSTA, E. Qualidade fisiológica de sementes de soja esverdeadas em diferentes tamanhos. Revista de Agricultura Neotropical, Cassilândia v. 2, n. 3, p. 39-43, 2015.

PEREIRA, W. A.; PEREIRA, S. M. A.; DIAS, D. C. F. S. Influence of seed size and water restriction on germination of soybean seeds and on early development of seedlings. Journal of Seed Science, Londrina, v. 35, n. 3, p. 316-322, 2013.
PROCÓPIO, S. O.; BALBINOT JUNIOR, A. A.; DEBIASI, H.; FRANCHINI, J. C.; PANISON, F. Plantio cruzado na cultura da soja utilizando uma cultivar de hábito de crescimento indeterminado. Revista de Ciências Agrárias/Amazonian Journal of Agricultural and Environmental Sciences, Belém, v. 56, n. 4, p. 319325, 2013.

Semeadura em fileira dupla e espaçamento reduzido na cultura da soja. Revista Agro@mbiente Online, Boa Vista, v. 8, n. 2, p. 212-221, 2014.

RANGEL, M. A. S.; MINUZZI, A.; PÌEREZAN, L.; TEODÓSIO, T. K. C.; ONO, F. B.; CARDOSO, P. C. Presença e qualidade de sementes esverdeadas de soja na região sul do estado do Mato Grosso do Sul. Acta Scientiarum Agronomy, Maringá, v. 33, n. 1, p. 127-132, 2011.

SOARES, M. M.; OLIVEIRA, G. L.; SORIANO, P. E.; SEKITA, M. C.; SEDIYAMA, T. Performance of soybean plants as function of seed size: II. Nutritional stress. Journal of Seed Science, Londrina, v. 35, n. 4, p. 419-427, 2013.

SOUZA, C. A.; GAVA, F.; CASA, R. T.; BOLZAN, J. M.; KUHNEM JUNIOR, P. R. Relação entre densidade de plantas e genótipos de soja Roundup ReadyTM. Planta Daninha, Viçosa, v. 28, n. 4, p. 887-896, 2010.

SUHRE, J. J.; WEIDENBENNER, N. H.; ROWNTREE, S. C.; WILSON, E. W.; NAEVE, S. L.; CONLEY, S. P.; CASTEEL, S. N.; DIERS, B. W.; ESKER, P. D.; SPECHT, J. E.; DAVIS, V. M. Soybean yield partitioning changes revealed by genetic gain and seeding rate interactions. Agronomy Journal, Madison, v. 106, n. 5, p. 1631-1642, 2014.

ZORATO, M. F.; PESKE, S. T.; TAKEDA, C.; FRANÇA NETO, J. B. Presença de sementes esverdeadas em soja e seus efeitos sobre seu potencial fisiológico. Revista Brasileira de Sementes, Londrina, v. 29, n. 1, p. 11-19, 2007. 
